\title{
Prevalence of Pineal Gland and Choroid Plexus Calcification Among Iraqi Patients Attending CT Scan Units
}

\author{
Prevalencia de Calcificación de la Glándula Pineal y del Plexo Coroideo Entre \\ Pacientes Iraquíes que Asisten a las Unidades de Tomografía Computarizada
}

Laith Thamer Al-Ameri; Eman Alaa Al-Zuhairi \& Heidi Mohammed Al-Shirwani

AL-AMERI, L. T.; AL-ZUHAIRI, E. A. \& AL-SHIRWANI, H. M. Prevalence of pineal gland and choroid plexus calcification among Iraqi patients attending CT scan units. Int. J. Morphol., 39(1):244-251, 2021.

SUMMARY: Pineal gland calcification is the most common physiological intracranial calcification followed by the choroid plexus calcification. The objective of the study was to determine the prevalence of the pineal gland and choroid plexus calcification among the Iraqi population attending computed tomography scan units in Baghdad, estimate the mean diameters of the pineal gland calcification, and to detect any correlation between these calcifications with age and sex. This multi-centric cross-sectional study examined 485 CT scans of Iraqi patients between the ages of 1 and 100 years attending CT scan units in the period 1 December 2018 to 1 April 2019. Descriptive and inferential statistics were used. The prevalence of pineal gland calcification was found to be $68 \%$ with the $30-39$ age group and male sex predominance. It was found to increase after the first decade of life without real consistency. The mean for pineal gland calcification anterior-posterior diameter was $4.55 \pm 2.13$ and the mean of the right-left diameter was 3.95 \pm 1.54 . These diameters were found to differ according to sex and age. Choroid plexus calcification was found to have a prevalence of $53.6 \%$. In most cases, choroid plexus calcification was found bilaterally (77.3\%). There was no difference in sex, but choroid plexus. In conclusion, calcification was noticed to increase gradually according to age. Both pineal gland and choroid plexus calcification have a relatively high prevalence. While pineal gland calcification formation was demonstrated to have a close relation to age and sex, choroid plexus calcification formation was noticed to relate only to age.

KEY WORDS: Pineal gland; Choroid plexus; Intracranial calcification.

\section{INTRODUCTION}

The pineal gland, choroid plexus, habenula, dura, and others areamong physiological intracranial calcifications in which pineal gland calcification (PGC) is the most common followed by the choroid plexus calcification (CPC) (Sutton, 2002).

The pineal gland is a small, conical structure,measuring about 6x7x3 mm in size (Snell, 2010; Mohammed et al., 2016) it averages $150 \mathrm{mg}$ in weight (Golan et al., 2002). The choroid plexus, on the other hand, is a network of capillaries and specialized ependymal cells that are located in the ventricular system (Liddelow, 2015). The pineal gland, as well as, the choroid plexus was noticed to calcify over advancing age (Modic et al., 1980; Kay \& Sandyk, 1991).

From a radiological point of view, PGCs are important markers that the pineal gland lies in the midline and any displacement suggests a space-occupying lesion in the intracranial cavity (Turgut et al., 2008).
Animal experiments have shown that pineal activity exhibits a circadian rhythm that is influenced by light, by which the gland is most active during darkness. The most important secretion of the pineal gland regulated by this circadian rhythm is melatonin. Many studies have demonstrated numerous effects of melatonin circulating mainly in the CSF and affecting sleep duration (Snell). Other functions may include regulation of reproductive function, starving off infection as an antioxidant and an anti-inflammatory neuro-protector, increasing longevity, and enhancing mood (Hall \& Guyton, 2010; Tan et al., 2018).

Other secretions by the pineal gland that were discovered recently include a psychedelic methylated molecule and neuro-steroids from cholesterol; the first (N, Ndimethyltryptamine) was suggested that is exclusively produced at birth, during dreaming, and/or near death to produce 'out of body' experience (Guchhait, 1976; Hall \& Guyton). It has been noticed that pineal gland size varies 
withthe environment of the organism so that the colder the habitat the larger the size of the gland. Other factors may adjust the pineal gland's size and may include body fat and sleep duration (Tan et al.).

The choroid plexus has several functions; first, it mediates cerebrospinal fluid (CSF) production. CSF acts as a filtration system medium that facilitates the removal of metabolic waste from the brain and exchange of biomolecules and xenobiotics into and out of the brain (Abbott et al., 2018). Second, the choroid plexus help forms the blood-cerebrospinal fluid barrier (BCSFB) (Laterra et al., 1999). Third, it is considered to be a major source of transferrin secretion that plays a part in iron homeostasis in the brain (Moos et al., 2007).

Choroid plexus is the second major place for normal intracranial calcification. Calcification is seen mostly in the atrial portions of the lateral ventricles, rarely seen in the third or fourth ventricle, or patients younger than nine years old (Kırog `lu et al., 2010).

Nowadays, there is a growing interest in the application of evidence-based approaches, molecular or genetic, to the prevention of aging-related pathological changes.

Recent research has demonstrated that there could be two origins of PGC that are in association with pinealocytes or with non-pinealocytes. Regardless of the mechanism of calcification, the result will jeopardizes the melatonin synthetic capacity of this gland and may be associated with a variety of neuronal diseases including neurodegenerative diseases (Alzheimer's, Myasthenia gravis), migraine, symptomatic intracerebral hemorrhage, symptomatic cerebral infarction, sleep disorders, defective sense of direction and pediatric primary brain tumor (Kay \& Sandyk; Mahlberg et al., 2008; Turgut et al.; Tuntapakul et al., 2016). Interestingly, PGC is mainly associated with brain-related disorders but not with other organ pathophysiologies while the decreased melatonin levels were detected in the blood which supplies all the tissues. This observation further supports the hypothesis that high levels of melatonin released directly into the CSF from the pineal gland serves as a biological circadian rhythm regulator and a neuronal antioxidant while the blood melatonin is the residue of the pineal melatonin (Marinescu et al., 2013; Reiter et al., 2014).

Although the mechanism of calcification of the choroid plexus is still unclear, studies suggest that injuries of various etiologies and dysfunctions within the small blood vessels of the brain that disrupt the calcium homeostasis could lead to calcification of the choroid plexus (Marinescu et al.). Many studies had been done to identify the clinical significance of $\mathrm{CPC}$; one study suggests that its size is positively correlated with the intensity of hallucination seen in schizophrenia (Sandyk, 1993). Another reported that CPC might be useful as a marker of suicidality in patients with schizophrenia and bipolar disorder (Sandyk \& Kay, 1991). Also, one recent study suggested that CPC was associated with brain atrophy, and with important cognitive dysfunctions (Marinescu et al.).

A study found that the prevalence of PGC was higher in western countries compared to African and Asian countries. Reports indicate a significant difference in the prevalence of PGC in African Americans (9.8\%)and White Americans (16 $\%$ ) (Adeloye \& Felson, 1974).

Various rates have been reported in some African and Asian countries, with the prevalence being $1.3 \%$ in Gambians, $5 \%$ in Nigerians, $9.9 \%$ in Japanese, $15.6 \%$ in Fijians, and $19.2 \%$ in Indians (Akano \& Bickler, 2003).

Recent studies reported the prevalence of PGC from different parts of the world; $58.8 \%$ in the USA, $68.5 \%$ in Turkey, and $51.7 \%$ in Brazil (Modic et al.; Turgut et al.; Alves et al., 2013).

Furthermore, a study in Kurdistan, Iraq, revealed that the prevalence of PGC among the study sample was $26.9 \%$ with the 51-60 age group and males having the highest incidence (Mohammed et al.).

A study was done that examined about 1,000 consecutive CT scans for calcification of the choroid plexus; found that the prevalence of calcification ranged from $0.5 \%$ in the first decade of life to $86 \%$ in the eighth decade (Kay \& Sandyk).

The objectives of this study are to determine the prevalence of pineal and choroid plexus calcifications among Iraqi population of patients attending CT scan units in the major public teaching hospitals in Baghdad and estimate mean diameters of the pineal gland calcification. As well as to find if there is any correlation between the occurrences of these calcifications regarding age and sex.

\section{MATERIAL AND METHOD}

This is a multi-centric cross-sectional study for the Iraqi population attendingCT scan units in different tertiary hospitals in Baghdad - Iraq. Recorded data were collected for all patients who were referred for a brain CT scan in the period from the 1st of December 2018 to 1st of April 2019.

A total of 485 cases were collected and enrolled the study after applying our inclusion/ exclusion criteria, non-Iraqi 
patients, those with pathologies that may show abnormal calcifications and cases with insufficient data regarding age, sex, or other required data were excluded from the study.

Data were collected for all enrolled cases with age and sex then investigated through RadiAnt DICOM viewer 4.6.9 program. CT scans were recorded for all cases through $5 \mathrm{~mm}$ slices axial images, all cases were carefully reviewed by two or more radiologists.

PGC was reported if present through any CT slice and was identified as a midline calcification in the posterior cranial fossa, with its antero-posterior and transverse diameters measured through the program tools. If PGC was noted in more than one slice, the slices with the largest diameter were chosen. Choroid plexus calcifications were reported if present in the lateral ventricles for each case. It is reported whether it is unilateral (right or left) or bilateral.

Data were entered into Microsoft Excel 2013 and analyzed through IBM-SPSS version 17 software. Cases were classified into 9 age groups. Descriptive statistics were used to calculate mean values for age, mean for PGC anteroposterior and transverse diameters, the prevalence of PGC and choroid plexus calcifications. Chi-square test was used to analyze male to female significance as well as to analyze significance in the relationship between age groups and the presence of CPC and PCG. The correlation between age and PGC diameters were analyzed using the Pearson correlation coefficient. Independent T-test was performed to analyze significance in the relation between sex and the PGC diameters measurements. P-value of $\leq 0.05$ was considered significant.

Ethical approval was obtained from the scientific unit at Al-Kindy College of medicine, University of Baghdad.

\section{RESULTS}

Out of the 485 CT scans evaluated, 238 (49\%) were from females and 247 (51\%) were from males. Pineal gland calcification was noted in 331 scans with a prevalence of $68 \%$. Of these scans; $185(55.89 \%)$ were from males and $146(44.1 \%)$ were from females, the difference was significant $(\mathrm{P}-$ value $=0.001)$, the prevalence of $\mathrm{PGC}$ in each sex is demonstrated in Table I. Participant's age ranged from 1 to 100 years with a mean of $46.47 \pm 21.59$ (Fig. 1). The prevalence of pineal gland calcification in age groups was $13.6 \%$ for $<9,31.1 \%$ for $10-19,66.7 \%$ for $20-29,87.8 \%$ for $30-39,76.8 \%$ for $40-49,81.2 \%$ for $50-59,74.2 \%$ for $60-69,64.9 \%$ for $70-79$ and $67.9 \%$ for $>80$; difference was significant (P-value $<0.001)$ (Table II). The highest prevalence was found in the 30-39 age group.

The mean for PGC antero-posterior diameter was $4.55 \pm 2.13 \mathrm{~mm}$ and the mean of the right-left diameter was $3.95 \pm 1.54 \mathrm{~mm}$. There was a significant positive correlation between the antero-posterior diameter measurement and age $(\mathrm{P}$-value $=0.018)$ but a non-significant correlation between age and the left-right diameter measurement $(\mathrm{P}$-value $=$ 0.076) (Table III), so that increasing age may be associated with an increase in the antero-posterior diameter measurement only. There was a significance difference between sexes in the right-left diameter measurement $(\mathrm{P}$ -

Table III. Correlation between age and pineal gland calcification diameters measurements in studied population

\begin{tabular}{lll}
\hline Diameter & Pearson correlation value & P-value \\
\hline Anterior-Posterior & 0.130 & 0.018 \\
Right-Left & 0.098 & 0.076 \\
\hline
\end{tabular}

Table I. Prevalence of pineal gland calcification regarding sex.

\begin{tabular}{lrrrrrr}
\hline Sex & Present & Percentage & Not present & Percentage & Total & P-value \\
\hline Male & 185 & 74.9 & 62 & 25.1 & 247 & $=0.001$ \\
Female & 146 & 61.3 & 92 & 38.7 & 238 & \\
\hline
\end{tabular}

Table II. Prevalence of pineal gland calcification in different age groups.

\begin{tabular}{|c|c|c|c|c|c|c|}
\hline \multirow{2}{*}{$\begin{array}{l}\text { Age Group } \\
<9\end{array}$} & \multirow{2}{*}{$\begin{array}{c}\text { Present } \\
3\end{array}$} & \multirow{2}{*}{$\begin{array}{c}\text { Percentage } \\
13.6\end{array}$} & \multirow{2}{*}{$\begin{array}{c}\text { Not present } \\
19\end{array}$} & \multirow{2}{*}{$\begin{array}{c}\text { Percentage } \\
86.4\end{array}$} & \multicolumn{2}{|c|}{ Total } \\
\hline & & & & & 22 & \multirow{9}{*}{$\begin{array}{l}\mathrm{P} \text {-value }< \\
0.001\end{array}$} \\
\hline $10-19$ & 14 & 31.1 & 31 & 68.9 & 45 & \\
\hline $20-29$ & 34 & 66.7 & 17 & 33.3 & 51 & \\
\hline $30-39$ & 43 & 87.8 & 6 & 12.2 & 49 & \\
\hline $40-49$ & 63 & 76.8 & 19 & 23.2 & 82 & \\
\hline $50-59$ & 69 & 81.2 & 16 & 18.8 & 85 & \\
\hline $60-69$ & 49 & 74.2 & 17 & 25.8 & 66 & \\
\hline $70-79$ & 37 & 64.9 & 20 & 35.1 & 57 & \\
\hline$>80$ & 19 & 67.9 & 9 & 32.1 & 28 & \\
\hline
\end{tabular}




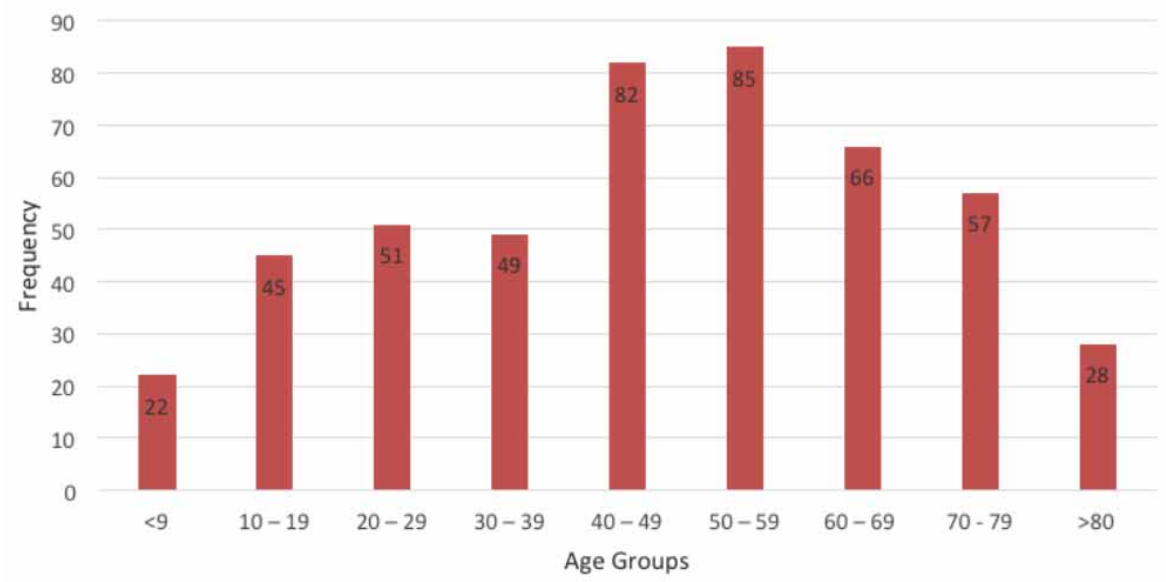

Fig. 1. Distribution of studied sample according to age groups.

value $=0.046)$ in which the mean right-left diameter was higher in males than in females. However, there was a nonsignificant difference in the antero-posterior diameter measurement $(\mathrm{P}$ value $=0.149)($ Table IV).

Table IV. Difference between sexes regarding pineal gland calcification diameter measurements.

\begin{tabular}{lllr}
\hline Diameter & \multicolumn{2}{c}{ Mean \pm STD } & P-value \\
\hline & Males & Females & \\
\hline Anterior-Posterior & $4.7 \pm 2.19$ & $4.36 \pm 2.04$ & 0.149 \\
Right-Left & $4.1 \pm 1.48$ & $3.76 \pm 1.59$ & 0.046 \\
\hline
\end{tabular}

Table V. Difference between sexes regarding choroid plexus calcification.

\begin{tabular}{|c|c|c|c|}
\hline Choroid plexus calcification & Sex & & \multirow{4}{*}{$\mathrm{P}-\mathrm{v}$ alue $=0.477$} \\
\hline & Male & Female & \\
\hline Present & 138 & 122 & \\
\hline Not present & 109 & 116 & \\
\hline
\end{tabular}
than 9 years of age. shown by CT scan. sample.
CPC was found in 260 scans $(53.6 \%)$ in which $201(77.3$ $\%)$ were bilateral, $43(16.5 \%)$ were found only on the right and $16(6.1 \%)$ were found only on the left (Fig. 2). There was no significant difference in sex regarding the presence of choroid plexus calcification $(\mathrm{P}$-value $=$ 0.477) (Table V). But statistics showed a significance difference in age distribution (P-value < 0.001) (Fig. 3), in which there was a gradual increment in the prevalence of CPC with aging demonstrated by the highest prevalence of $75 \%$ found in patients older than 80 years and no cases in patients younger

Figure 4 shows examples of pineal and choroid plexus calcifications for different cases enrolled in the study as

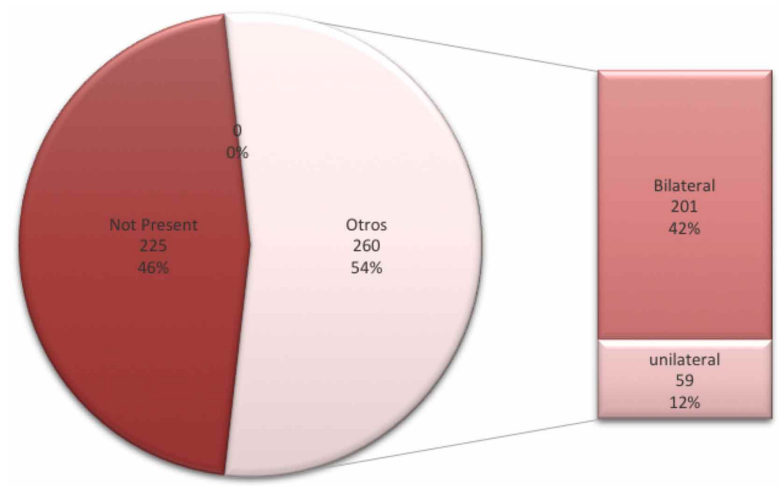

Fig. 2. Prevalence of choroid plexus calcification in studied

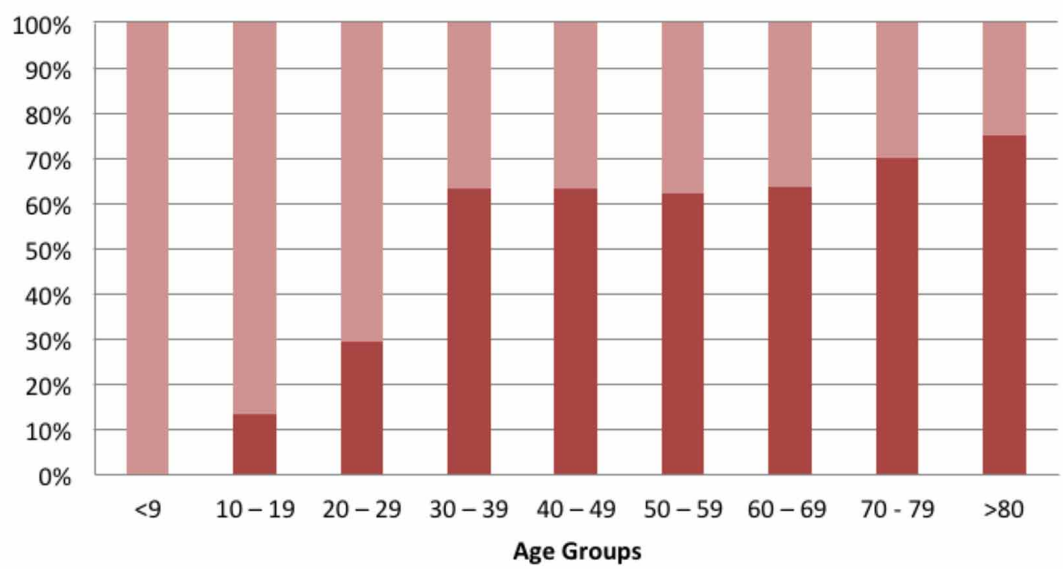

- Present $\quad$ Not present
Fig. 3. Prevalence of choroid plexus calcification in different age groups. 

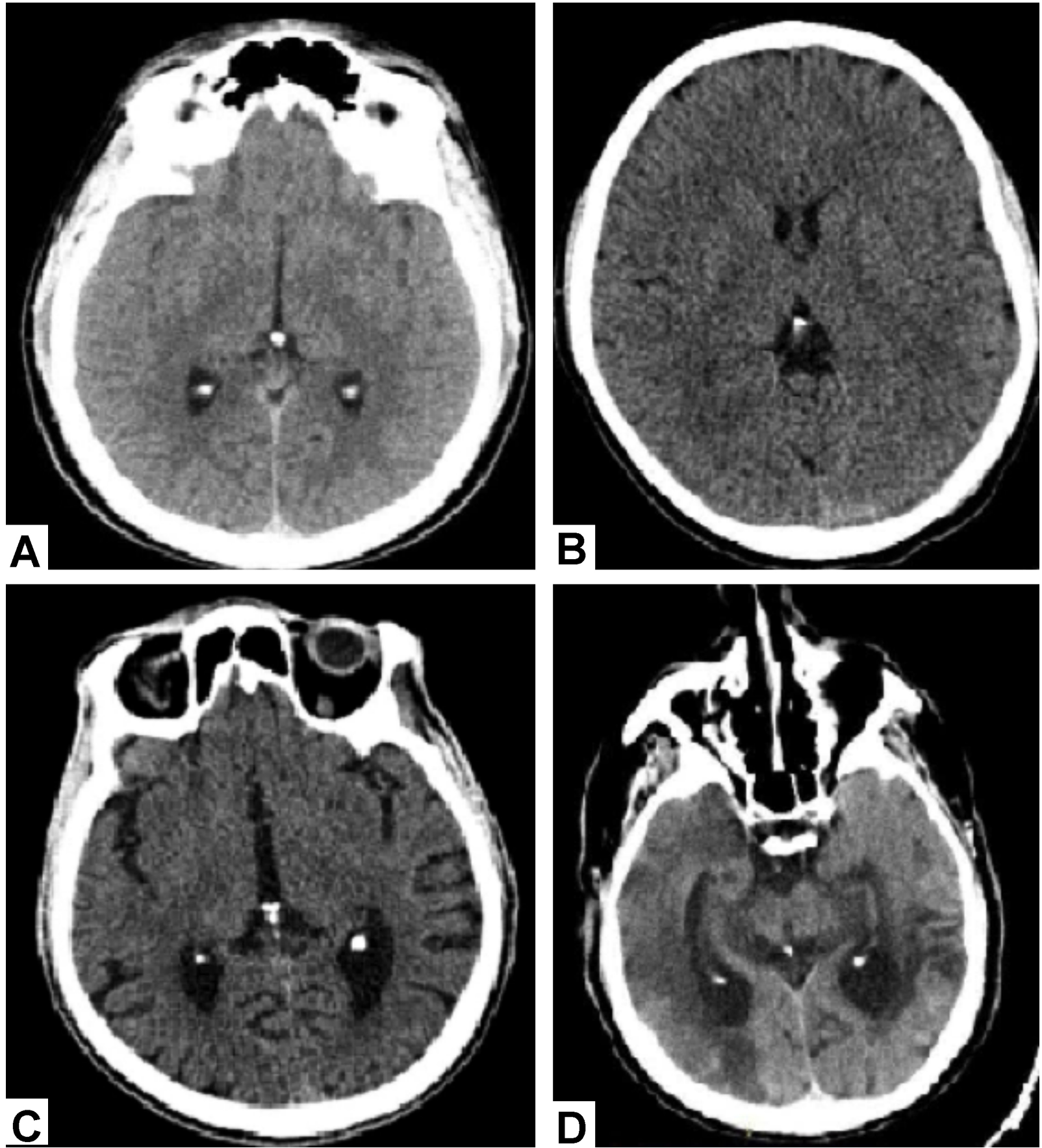

Fig. 4. A- a 20-year-old male with pineal and choroid plexus calcification. B- a 16-year- old female with pineal gland calcification. C-a 70-year-old male with pineal and choroid plexus calcification. D- a 78-year.old female with pineal and choroid plexus calcification.

\section{DISCUSSION}

The Pineal gland and choroid plexus and their relationship to numerous neurodegenerative disorders have been a topic of interest to the medical community. The prevalence of PGC has been studied by many literatures previously. However, only a few studies regarded PGC and $\mathrm{CPC}$ to age and sex. 
The prevalence of PGC in this study's population was $68 \%$, compared with a study in Iraq, Kurdistan region (Mohammed et al.) it's considered a high prevalence as it found the prevalence of PGC to be $26.9 \%$. This can be explained by the fact that this study evaluated CT scans while Iraqi Kurdistan's study evaluated skull X-ray scans. Radiologically it's widely accepted that CT is a more sensitive detector of intracranial calcifications. Moreover, in a previous postmortem study (Trentini et al., 1987) it was observed that pineal calcium content was significantly higher in individuals who died in summer compared to those who died in winter, which indicates an association between sunlight exposure and rate of PGC. It is well known that sunlight exposure in Iraqi Kurdistan is less than that in the middle or south of Iraq, which could explain the significant difference in the prevalence (Al-Hassany, 2017). In another study, it was demonstrated that altitude significantly alters the degree of PGC. Interestingly high altitude was found to decrease the degree of PGC which may be another factor to affect PGC prevalence between this study's population and IraqiKurdistan's as it is known that the altitude in Iraqi Kurdistan is higher than in other parts of Iraq (Turgut et al.; Al- Hassany).

PGC prevalence in this study was fairly equal to the incidence of PGC in a cohort study in Turkey with an incidence of $68.5 \%$. Although their study found that deprival of sunlight exposure may be a causative factor for the development of PGC in humans (Turgut et al.). However, there were conflicting opinions regarding the effect of sunlight exposure on PGC formation (Trentini et al.; Al-Hassany).

In Iran the PGC incidence is around $71 \%$ (Daghighi et al., 2007) and in African (Ethiopia), it is roughly $72 \%$ (Admassie \& Mekonnen, 2009) in subtropical Brazil it's about $51.7 \%$ (Alves et al.) and in the USA it's $58.8 \%$ (Modic et $a l$.). This suggests that PGC is affected to a higher degree by geographical factors aside from age and sex that will be discussed next.

In literature, a vast majority of the reports indicate that PGC can be seen as early as the second decade of life. In general, the demographic finding of this study corresponds with literature, with the increasing prevalence of PGC with aging. Although the increase in PGC prevalence with age is not consistent, currently, it has been understood that PGC is a regulated and reversible process, rather than merely being a passive phenomenon (Tan et al.).

In a study by Chang et al. (1981), it was pointed that PGC in children under the age of 10 has a pathologic significance, which suggests the possibility of the presence of a neoplasm involving the pineal gland, such as germinoma or teratoma. However, another radiological study of children,
Winkler \& Helmke (1987) found a significant percentage of physiological PGC even between 0 and 6 years of age, ranging from 2.9-4.2\%. When compared, the prevalence of PGC in this study was significantly higher $(13.6 \%)$ than those mentioned above in patients younger than 9 years of age. This might be due to the overall higher prevalence in this study's sample, while a study in Iraqi Kurdistan (Mohammed et al.,) found an overall prevalence of $26.9 \%$ and no cases of PGC in patients younger than 10 years. Another cause might be that some cases were taken from an emergency CT scan unit so it is possible that they were referred due to clinical pathological conformational diagnosis. So that with the lack of clinical history we cannot determine the real cause of this obviously high prevalence in this age group. However, a larger sample size might be needed for this age group to obtain more accurate results.

A possible clue to sex-related differences, in which there's a higher prevalence in males, is attributed to the interaction of sex hormones with the process of PGC formation. This finding is consistent with previous literature (Modic et al.; Moos et al.; Turgut et al.; Alves et al.). It was found that serum melatonin level showed a significant drop in pubertal boys, preceding the rise in testosterone and gonadotropins (Turgut et al.). There is evidence that melatonin has anti-estrogenic properties by stimulating progesterone production that opposes the action of estrogens (Sandyk et al., 1992). Interestingly, female pineal glands are heavier and more calcified during menopausal age whereas in the postmenopausal period pineal calcium content seems to decline to levels below those of men (Pitch et al., 2004). These observations could suggest a relationship between PGC and sex hormones, although the mechanisms underlying the formation of PGC are still unclear.

Compared to a study in the USA (Modic et al.), in which the antero-posterior diameter was $3.73 \pm 1.63 \mathrm{~mm}$ and the right-left diameter was $3.47 \pm 1.31 \mathrm{~mm}$, the mean of PGC in the current study was slightly higher $(4.55 \pm 2.13 \mathrm{~mm})$ for the antero-posterior diameter measurement and approximate $(3.95 \pm 1.54 \mathrm{~mm})$ for the right-left diameter measurement. To our knowledge there are no studies concerning the relationship between age or sex and these measurements, and there is no explanation to the positive correlation between either the age or sex to one of the measurement and not the other, or the fact that either sex or age correlates with the opposite measurement the second variable correlates to.

On the other hand, CPC is a less complex topic, because choroid plexus plays no hormonal role and its calcification shows no difference between sex and ethnic groups as does PGC. Studies on CPC are not numerous, among which, a study in Brazil (Alves et al.). When comparing the prevalence of 
CPC between Brazil's and this study's finding, there was an obvious difference, with a prevalence of $53.6 \%$ in this study and $42.6 \%$ in Brazil. Both studies agreed that the vast majority of CPC was found bilaterally, $77.3 \%$ in this study and $82.1 \%$ in Brazil's study. The difference in the prevalence can be attributed to the fact that their study examinations were performed using a single-slice helical CT scanner, that could have diminished the diagnostic accuracy in detecting CPC, especially for younger subjects. The mechanism of CPC formation is still unclear, but it has been approved that the prevalence of CPC increases gradually with age (Kay \& Sandyk), which corresponds to this study's finding. However, $\mathrm{CPC}$ is regarded by many studies as a pathological condition (Marinescu et al.; Pitch et al.), and since this study lacks any clinical information on the CT scan referral cause, CPC association to age cannot be determined for sure.

The major limitation of this study is the lack of clinical or laboratory data on the functions of the pineal gland, which made the ability to assess the effect of these calcifications on neurological dysfunction impossible in a clinically relevant way. Another limitation in this study is the lack of consideration of environmental factors that may affect the formation of these calcifications, as it has been mentioned above that there could be a possible role of sunlight exposure and altitude on PGC formation.

\section{CONCLUSIONS}

The prevalence of PGC was found to be high among the studied population, with male predominance. PGC prevalence was found to increase with age with a higher prevalence in the 30-39 age group. The mean of PGC anteroposterior and right-left diameters were calculated and were found to differ according to sex and age in an incoherent manner.

CPC was found to have a lower prevalence than PGC. In most cases, CPC was found bilaterally. There was no difference in sex, but CPC was noticed to increase gradually according to age.

AL-AMERI, L. T.; AL-ZUHAIRI, E. A. \& AL-SHIRWANI, H. M. Prevalencia de calcificación de la glándula pineal y del plexo coroideo entre pacientes iraquíes que asisten a las unidades de tomografía computarizada. Int. J. Morphol., 39(1):244-251, 2021.

RESUMEN: La calcificación de la glándula pineal es la calcificación intracraneal fisiológica más común después de la calcificación del plexo coroideo. El objetivo del estudio fue determinar la prevalencia de calcificación de la glándula pineal y del plexo coroideo entre la población iraquí que asiste a las unidades de tomografía computarizada en Bagdad, estimar los diámetros medios de la calcificación de la glándula pineal y detectar la posible correlación entre estas calcificaciones con la edad y el sexo. Este estudio transversal multicéntrico examinó 485 tomografías computarizadas de pacientes iraquíes entre 1 y 100 años de edad que asistieron a unidades de tomografía computarizada en el período del 1 de diciembre de 2018 al 1 de abril de 2019. Se utilizaron estadísticas descriptivas e inferenciales. Se encontró una prevalencia de calcificación de la glándula pineal del $68 \%$ con predominio del sexo masculino en el grupo de 30 a 39 años. Se observó que aumentaba después de la primera década de vida sin una coherencia real. La media del diámetro anteroposterior de la calcificación de la glándula pineal fue de 4,55 $\pm 2,13$ y la media del DIÁMETRO derecho-izquierdo fue de 3,95 \pm 1,54; estos diámetros difieren según el sexo y la edad. La calcificación del plexo coroideo tiene una prevalencia del 53,6 \%. En la mayoría de los casos, la calcificación del plexo coroideo se encontró de forma bilateral (77,3 $\%)$. No hubo diferencia de sexo, no obstante en el plexo coroideo se observó que la calcificación aumentaba gradualmente según la edad. Tanto la calcificación de la glándula pineal como del plexo coroideo tienen una prevalencia relativamente alta. Si bien se demostró que la formación de calcificación de la glándula pineal está relacionada con la edad y el sexo, se observó que la formación de calcificación del plexo coroideo se relaciona solo con la edad.

PALABRAS CLAVE: Glándula pineal; Plexo coroideo; Calcificación intracraneal.

\section{REFERENCES}

Abbott, N. J.; Pizzo, M. E.; Preston, J. E.; Janigro, D. \& Thorne, R. G. The role of brain barriers in fluid movement in the CNS: is there a 'glymphatic' system? Acta Neuropathol., 135(3):387-407, 2018.

Adeloye, A. \& Felson, B. Incidence of normal pineal gland calcification in skull roentgenograms of black and white Americans. Am. J. Roentgenol. Radium Ther. Nucl. Med., 122(3):503-7, 1974.

Admassie, D. \& Mekonnen, A. Incidence of normal pineal and chroids plexus calcification on brain CT (computerized tomography) at Tikur Anbessa Teaching Hospital Addis Ababa, Ethiopia. Ethiop. Med. J., 47(1):55-60, 2009.

Akano, A. \& Bickler, S. W. Pineal gland calcification in sub-Saharan Africa. Clin. Radiol., 58(4):336-7, 2003.

Al-Hassany, G. S. Estimation the best areas of Sun duration hours in Iraq by applying IDW type of interpolation techniques by using GIS program. Iraqi J. Sci., 58(1A):182-91, 2017.

Alves, G.; Cordenonsi, I.; Magno, P.; Werle, N. \& Haygert, C. Pineal gland and choroid plexus calcifications on CT: a retrospective study in a Brazilian subtropical city. Internet J. Hum. Anat., 2(1):1-7, 2013.

Chang, C. G.; Kageyama, N.; Kobayashi, T.; Yoshida, J. \& Negoro, M. Pineal tumors: clinical diagnosis, with special emphasis on the significance of pineal calcification. Neurosurgery, 8(6):656-68, 1981.

Daghighi, M. H.; Rezaei, V.; Zarrintan, S. \& Pourfathi, H. Intracranial physiological calcifications in adults on computed tomography in Tabriz, Iran. Folia Morphol. (Warsz.), 66(2):115-9, 2007.

Golan, J.; Torres, K.; Stas'kiewicz, G. J.; Opielak, G. \& Maciejewski, R. Morphometric parameters of the human pineal gland in relation to age, body weight and height. Folia Morphol. (Warsz.), 61(2):111-3, 2002.

Guchhait, R. B. Biogenesis of 5-methoxy-N,N-dimethyltryptamine in human pineal gland. J. Neurochem., 26(1):187-90, 1976. 
Hall, J. E. \& Guyton, A. C. Guyton and Hall Textbook of Medical Physiology. $12^{\text {th }}$ ed. Philadelphia, Saunders, 2010.

Kay, S. R. \& Sandyk, R. Experimental models of schizophrenia. Int. J. Neurosci., 58(1-2):69-82, 1991.

Kıroglu, Y.; Callı, C.; Karabulut, N. \& Oncel, C. Intracranial calcifications on CT. Diagn. Interv. Radiol., 16(4):263-9, 2010.

Laterra, J.; Keep, R.; Betz, L. A. \& Goldstein, G. W. Blood-Cerebrospinal Fluid Barrier. Basic Neurochemistry: Molecular, Cellular and Medical Aspects. Philadelphia, Lippincott-Raven, 1999.

Liddelow, S. A. Development of the choroid plexus and blood-CSF barrier. Front. Neurosci., 9:32, 2015.

Mahlberg, R.; Walther, S.; Kalus, P.; Bohner, G.; Haedel, S.; Reischies, F. D.; Kühl, K. P.; Hellweg, R. \& Kunz, D. Pineal calcification in Alzheimer's disease: An in vivo study using computed tomography. Neurobiol. Aging, 29(2):203-9, 2008.

Marinescu, I.; Udris, toiu, I. \& Marinescu, D. Choroid plexus calcification: clinical, neuroimaging and histopathological correlations in schizophrenia. Rom. J. Morphol. Embryol., 54(2):365-9, 2013.

Modic, M. T.; Weinstein, M. A.; Rothner, A. D.; Erenberg, G.; Duchesneau, P. M. \& Kaufman, B. Calcification of the choroid plexus visualized by computed tomography. Radiology, 135(2):369-72, 1980.

Mohammed, K. A.; Boakye, E. A.; Ismail, H. A.; Geneus, C. J.; Tobo, B. B.; Buchanan, P. M. \& Zelicott, A. P. Pineal gland calcification in kurdistan: a cross-sectional study of 480 roentgenograms. PLoS One, 11(7):e0159239, 2016.

Moos, T.; Nielsen, T. R.; Skjørringe, T. \& Morgan, E. H. Iron trafficking inside the brain. J. Neurochem., 103(5):1730-40, 2007.

Pitch, T.; Stendel, R.; Stoltenburg-Didinger, G. \& Brock, M. Giant intracerebral choroid plexus calcification. Acta Neurochir. (Wien), 146(11):1259-61, 2004.

Reiter, R. J.; Tan, D. X.; Kim, S. J. \& Cruz, M. H. C. Delivery of pineal melatonin to the brain and SCN: role of canaliculi, cerebrospinal fluid, tanycytes and Virchow-Robin perivascular spaces. Brain Struct. Funct., 219(6):1873-87, 2014

Sandyk, R. \& Kay, S. R. Choroid plexus calcification: a biological marker of suicidality. Int. J. Neurosci., 57(1-2):95-7, 1991.

Sandyk, R. Choroid plexus calcification as a possible marker of hallucinations in schizophrenia. Int. J. Neurosci., 71(1-4):87-92, 1993.

Sandyk, R.; Anastasiadis, P. G.; Anninos, P. A. \& Tsagas, N. Is the pineal gland involved in the pathogenesis of endometrial carcinoma. Int. J. Neurosci., 62(1-2):89-96, 1992.

Snell, R. S. Clinical Neuroanatomy. Philadelphia, Lippincott \& Wilkins, 2010.

Sutton, D.; Reznek, R. \& Murfitt, J. Textbook of Radiology and Imaging. London, Churchill Livingstone, 2002.

Tan, D. X.; Xu, B.; Zhou, X. \& Reiter, R. J. Pineal calcification, melatonin production, aging, associated health consequences and rejuvenation of the pineal gland. Molecules, 23(2):301, 2018.

Trentini, G. P.; De Gaetani, S. \& Criscuolo, M. Pineal Calcification in Different Physiopathological Conditions in Humans. In: Trentini, G. P.; De Gaetani, C. \& Pevet, P. (Eds.). Fundamentals and Clinics in Pineal Research. New York, Raven Press, 1987. pp.291-304.

Tuntapakul, S.; Kitkhuandee, A.; Kanpittaya, J.; Johns, J. \& Johns, N. P. Pineal calcification is associated with pediatric primary brain tumor. Asia Pac. J. Clin. Oncol., 12(4):e405-e410, 2016.

Turgut, A. T.; Karakas, , H. M.; Ozsunar, Y.; Altın, L.; Ceken, K.; Alıcıg `lu, B.; Sönmez, I.; Alparslan, A.; Yürümez, B.; Celik, T.; et al. Age-related changes in the incidence of pineal gland calcification in Turkey: A prospective multicenter CT study. Pathophysiology, 15(1):41-8, 2008.

Winkler, P. \& Helmke, K. Age-related incidence of pineal gland calcification in children: a roentgenological study of 1,044 skull films and a review of the literature. J. Pineal Res., 4(3):247-52,1987.

\author{
Corresponding author: \\ Laith Thamer Al-Ameri \\ Al-Kindy College of Medicine \\ University of Baghdad \\ Baghdad \\ IRAQ
}

Email: laith.thamer@yahoo.com

Received: 07-07-2020

Accepted: 08-09-2020 